\title{
Thrombocytopenia Possibly Induced By Dabigatran: A Case Report
}

Arianna Deidda ${ }^{1,5^{*}}$, Maurizio Rapallo ${ }^{2}$, Maria Dolores Sofia ${ }^{3}$, Leandra Meloni ${ }^{4}$, Simona Francesca Lampus ${ }^{1}$, Claudia Pisanu ${ }^{5}$, Giovanna Cadeddu ${ }^{5}$, Donatella Garau $^{6}$, Maria Del Zompo ${ }^{5}$ and Maria Erminia Stochino ${ }^{1}$

${ }^{1}$ Sardinian Regional Center of Pharmacovigilance, Unit of Clinical Pharmacology, University Hospital of Cagliari (AOUCA), Cagliari, Italy

${ }^{2}$ Unit of Internal Medicine no. 1, AOUCA, Cagliari, Italy

${ }^{3}$ Laboratory of Chemical-Clinical Analyses and Microbiology, AOUCA, Cagliari, Italy

${ }^{4}$ Service of Pharmacy, AOU CA, Cagliari, Italy

${ }^{5}$ Section of Neuroscience and Clinical Pharmacology, Department of Biomedical Sciences, University of Cagliari, Cagliari, Italy

${ }^{6}$ Regional Councillorship of Health, "Regione Autonoma della Sardegna", Cagliari, Italy

"Corresponding author: Arianna Deidda, MD, Unit of Clinical Pharmacology, "San Giovanni di Dio" Hospital, Via Ospedale 54,09124 Cagliari, Italy, Tel: +39 070 6092438; Fax: +39 070 653584; E-mail: arianna.deidda@unica.it

Received date: June 29, 2015; Accepted date: July 10, 2015; Published date: July 15, 2015

Copyright: ( 2015 Deidda A, et al. This is an open-access article distributed under the terms of the Creative Commons Attribution License, which permits unrestricted use, distribution, and reproduction in any medium, provided the original author and source are credited.

\begin{abstract}
Dabigatran, a reversible direct thrombin inhibitor, is a new oral anticoagulant developed for long-term prevention of thromboembolic disorders whose safety profile is not completely known yet. Here we report a case of dabigatraninduced severe thrombocytopenia which was signaled to our Regional Center of Pharmacovigilance.

An 84 year old Caucasian man started dabigatran due to a permanent atrial fibrillation. Five months later he was admitted to the emergency department following a skin eruption. Physical examination revealed a hemorrhagic necrotic skin lesion in the lumbosacral region. Blood tests showed a severe thrombocytopenia, with a platelet count of $16.000 \mathrm{~mm}$. The patient was hospitalized and dabigatran was promptly suspected to be the causative agent of thrombocytopenia, so the drug was discontinued and one week later platelet count completely normalized. Segmental distribution of the cutaneous lesions suggested hemorrhagic herpes zoster, so the patient was treated with oral valacyclovir and local gentamicin, with complete remission after a few months.

To the best of our knowledge, severe thrombocytopenia induced by dabigatran has never been previously reported in literature, although the Italian National Pharmacovigilance database of the Italian Medicines Agency reports seven cases of thrombocytopenia associated with dabigatran, including ours. According to Naranjo algorithm severe thrombocytopenia was possibly due to dabigatran, which suggests a careful monitoring of patients being treated with this drug.
\end{abstract}

\section{Keywords:}

Dabigatran; Thrombocytopenia; Hemorrhagic herpes zoster

\section{Introduction}

New oral anticoagulants (OACs) that directly inhibit Factor Xa or thrombin have been developed for the long-term prevention of thromboembolic disorders. The new OACs have rapid onset of action, low potential for food and drug interactions, and a predictable anticoagulant effect that removes the need for routine monitoring. Dabigatran etexilate is a low-molecular-weight, non-active pro-drug that is administered orally and converted rapidly to its active form dabigatran, a potent, competitive and reversible direct thrombin inhibitor. Although dabigatran has fewer risks compared to warfarin, its safety profile is not completely known yet [1].

Recently, some isolated case reports have been issued, hinting at dabigatran as an emerging treatment option in Heparin-Induced Thrombocytopenia, but, although this clinical use of the drug might be theoretically correct, available data are not sufficient enough to recommend it $[2,3]$.
Here we report a case of thrombocytopenia in a patient treated with dabigatran, which was signaled to our Regional Center of Pharmacovigilance and was reported to the Italian regulatory authority (report number of Italian spontaneous-reporting database: 225790).

\section{Case Report}

An 84 year old man was admitted to the emergency department with a skin eruption. Physical examination revealed a hemorrhagic necrotic skin lesion in the lumbosacral region. The man had been treated since 2008 with eprosartan mesylate $600 \mathrm{mg} /$ day for hypertension and since 2005 with propionyl-L-carnitine $500 \mathrm{mg} /$ day for venous insufficiency. Five months prior to the admission, dabigatran etexilate $220 \mathrm{mg}$ /day had been commenced for the management of a permanent atrial fibrillation.

Laboratory test results showed a severe thrombocytopenia (platelets $16,000 \mathrm{~mm} 3$ ), haemoglobin $14.2 \mathrm{~g} / \mathrm{dL}$, creatinine $1.41 \mathrm{mg} / \mathrm{dl}$, Glomerular Filtration Rate $35 \mathrm{ml} / \mathrm{min}$ (estimated using CockcroftGault equation), azotemia $27 \mathrm{mg} / \mathrm{dl}$, INR prothrombin time (PT) 1.23, activated partial thromboplastin time (APTT) 35 seconds and urinalysis showed microscopic haematuria. There was no evidence of 
Page 2 of 3

pseudothrombocytopenia. The patient's medical history did not reveal any drug allergies. Viral markers of hepatitis B and C and neoplastic markers were all negative. The patient was hospitalized and, in view of the possible role of dabigatran in the development of thrombocytopenia, this drug was discontinued. After 7 days platelet count was back to normal (Figure 1).

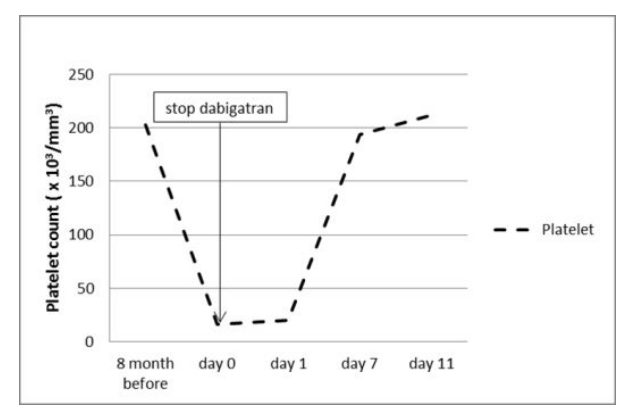

Figure 1: Course of dabigatran-induced thrombocytopenia.

Segmental distribution of the painful cutaneous lesions suggested hemorrhagic herpes zoster, which was treated with oral valacyclovir 3 $\mathrm{g} /$ day for 10 days and local gentamicin application. The patient was discharged and dabigatran was replaced with warfarin. The skin lesions showed signs of a slow recovery after a few months (Figure 2).

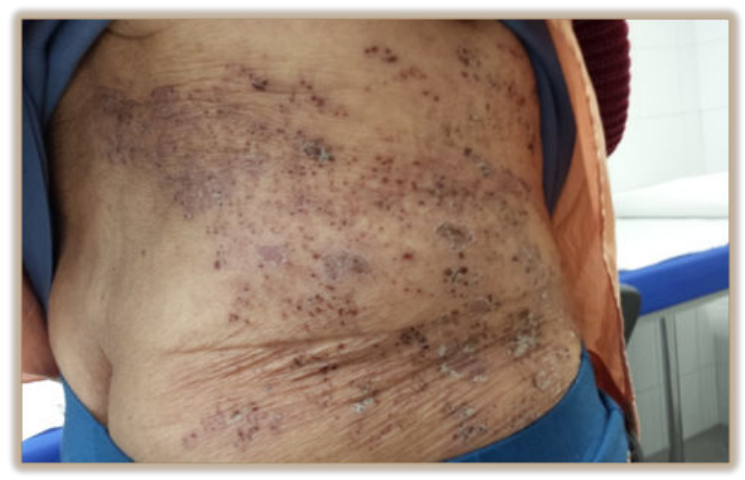

Figure 2: Hemorrhagic herpes zoster in a patient with dabigatraninduced thrombocytopenia, one month after discharge.

\section{Discussion}

To the best of our knowledge, severe thrombocytopenia induced by dabigatran has never been previously reported in literature. The drug's summary of product characteristics reports thrombocytopenia as an adverse drug reaction signaled during postmarketing surveillance, although the severity of this reaction is not specified. In this case, according to the Naranjo algorithm [4], severe thrombocytopenia was possibly due to dabigatran. Specifically, after dabigatran was stopped, platelet count returned to normal in one week, as expected according to the literature on drug-induced thrombocytopenia [5], but we cannot completely exclude a role of the herpes zoster infection because there is reasonable documentation for acute thrombocytopenia developing after varicella-zoster virus (VZV) infection [6]. It could be hypothesized that dabigatran-induced thrombocytopenia made the patient susceptible to the development of hemorrhagic herpes zoster or that the previous exposure to dabigatran has increased the risk of thrombocytopenia related to herpes zoster. In fact, hemorrhagic herpes zoster is an atypical form of cutaneous varicella zoster virus infection which correlates with immunodepression, coagulopathy and thrombocytopenia [7].

The Italian National Pharmacovigilance database of the Italian Medicines Agency, which contains all spontaneous reports of adverse drug reactions observed in Italy, was searched for reports of thrombocytopenia associated with dabigatran between January 1st 2008 (the European Commission granted a marketing authorization for Pradaxa-dabigatran etexilate on March 2008) and January 20th 2015 (Table 1): seven cases were found, including ours, four of which were serious. In all cases dabigatran was the only medication suspected and in all cases, except ours, the causality assessment, based on the Naranjo algorithm, resulted probable. Our case is characterized by a longer time of exposure to the drug (170 days) compared to the other cases found in the database, although we do not know the date of onset of thrombocytopenia because no blood counts were available prior to the admission.

We can conclude that thrombocytopenia is a rare but potentially life-threatening complication probably induced by dabigatran and suggest a careful monitoring of patients being treated with this drug. All physicians who use dabigatran need to be aware of thrombocytopenia induced by dabigatran because, although this drug offers an attractive therapy option for Heparin-Induced Thrombocytopenia, it could induce thrombocytopenia itself. Spontaneous reporting of suspected adverse drug reactions is to be considered as a tool for better understanding the whole safety profile of new drugs.

\begin{tabular}{|c|c|c|c|c|c|c|c|c|c|c|}
\hline Case & Sex & Age (years) & $\begin{array}{l}\text { Seriousnes } \\
\mathrm{s}\end{array}$ & $\begin{array}{l}\text { Therapeutic } \\
\text { indication }\end{array}$ & $\begin{array}{l}\text { Daily } \\
\text { dose } \\
\text { (mg) }\end{array}$ & $\begin{array}{l}\text { Duration of } \\
\text { drug } \\
\text { exposure } \\
\text { (days) }\end{array}$ & $\begin{array}{l}\text { Reported } \\
\text { adverse } \\
\text { reaction }\end{array}$ & $\begin{array}{l}\text { Platelet } \\
\text { count } / \mathrm{mm} 3\end{array}$ & $\begin{array}{l}\text { Concomitant } \\
\text { drugs }\end{array}$ & $\begin{array}{l}\text { Year } \\
\text { onset }\end{array}$ \\
\hline 1 & M & 51 & $\begin{array}{l}\text { Requires } \\
\text { inpatient } \\
\text { hospitalizati } \\
\text { on or } \\
\text { prolongatio } \\
\text { n of existing } \\
\text { hospitalizati } \\
\text { on }\end{array}$ & $\begin{array}{l}\text { Limb } \\
\text { immobilisatio } \\
\mathrm{n}\end{array}$ & 220 & 30 & $\begin{array}{l}\text { Oral mucosa } \\
\text { ecchymosis, } \\
\text { thrombocytopen } \\
\text { ia }\end{array}$ & 1,000 & None & 2011 \\
\hline
\end{tabular}


Citation: Deidda A, Rapallo M, Sofia MD, Meloni L, Francesca S, et al. (2015) Thrombocytopenia Possibly Induced By Dabigatran: A Case

Page 3 of 3

\begin{tabular}{|c|c|c|c|c|c|c|c|c|c|c|}
\hline 2 & $\mathrm{~F}$ & 77 & Not serious & $\begin{array}{l}\text { Thrombosis } \\
\text { prophylaxis }\end{array}$ & 220 & 21 & $\begin{array}{l}\text { Thrombocytope } \\
\text { nia }\end{array}$ & 83,400 & Indometacine & 2012 \\
\hline $3^{*}$ & M & 84 & $\begin{array}{l}\text { Requires } \\
\text { inpatient } \\
\text { hospitalizati } \\
\text { on or } \\
\text { prolongatio } \\
\text { n of existing } \\
\text { hospitalizati } \\
\text { on }\end{array}$ & $\begin{array}{l}\text { Atrial } \\
\text { fibrillation }\end{array}$ & 220 & 170 & $\begin{array}{l}\text { Thrombocytope } \\
\text { nia }\end{array}$ & 16,000 & $\begin{array}{l}\text { Eprosartan, } \\
\text { levocarnitine }\end{array}$ & 2013 \\
\hline 4 & M & 70 & Not serious & Unknown & 300 & 23 & $\begin{array}{l}\text { Thrombocytope } \\
\text { nia }\end{array}$ & 108,000 & None & 2013 \\
\hline 5 & M & 87 & Not serious & $\begin{array}{l}\text { Atrial } \\
\text { fibrillation }\end{array}$ & 220 & 120 & $\begin{array}{l}\text { Gastralgia, } \\
\text { abnormal loss of } \\
\text { weight, } \\
\text { anaemia, } \\
\text { asthenia, } \\
\text { thrombocytopen } \\
\text { ia }\end{array}$ & 57,200 & $\begin{array}{l}\text { Oxatomide, } \\
\text { bisoprolol }\end{array}$ & 2014 \\
\hline 6 & $\mathrm{~F}$ & 81 & $\begin{array}{l}\text { Requires } \\
\text { inpatient } \\
\text { hospitalizati } \\
\text { on or } \\
\text { prolongatio } \\
\text { n of existing } \\
\text { hospitalizati } \\
\text { on }\end{array}$ & $\begin{array}{l}\text { Atrial } \\
\text { fibrillation }\end{array}$ & 220 & 5 & $\begin{array}{l}\text { Anaemia, } \\
\text { thrombocytopen } \\
\text { ia }\end{array}$ & $\begin{array}{l}\text { Unknown } \\
\text { (In the free text } \\
\text { box: severe } \\
\text { thrombocytopenia } \\
\text { ) }\end{array}$ & $\begin{array}{l}\text { Furosemide, } \\
\text { pantoprazole, } \\
\text { canrenoate } \\
\text { potassium, } \\
\text { levofloxacin, } \\
\text { potassium } \\
\text { chloride, } \\
\text { irbesartan, } \\
\text { atorvastatin, } \\
\text { allopurinol, } \\
\text { bisoprolol }\end{array}$ & 2014 \\
\hline 7 & M & 72 & Not serious & $\begin{array}{l}\text { Atrial } \\
\text { fibrillation }\end{array}$ & 220 & 68 & $\begin{array}{l}\text { Thrombocytope } \\
\text { nia }\end{array}$ & 85,000 & $\begin{array}{l}\text { Flecainide, } \\
\text { bisoprolol }\end{array}$ & 2014 \\
\hline
\end{tabular}

Table 1: Summary of cases of dabigatran-induced thrombocytopenia from the Italian National Pharmacovigilance Database (between January 1st 2008 and January 20th 2015).

\section{Acknowledgement}

This work was supported by the Sardinian Regional Councillorship of Health with a grant dedicated to the Sardinian Regional Center of Pharmacovigilance. The authors wish to thank Ms Enrica Mosca for reviewing and editing the manuscript.

\section{References}

1. Hankey GJ, Eikelboom JW (2011) Dabigatran etexilate: a new ora thrombin inhibitor. Circulation 123: 1436-1450.

2. Mirdamadi A (2013) Dabigatran, a direct thrombin inhibitor, can be a life-saving treatment in heparin-induced thrombocytopenia. ARYA Atheroscler 9: 112-114.
3. Anniccherico FJ, Alonso JL, Urbieta M, Pérez Ricarte S (2012) Dabigatran as a therapeutic possibility in heparin-induced thrombocytopenia type II. An Sist Sanit Navar 35: 521-524.

4. Naranjo CA, Busto U, Sellers EM, Sandor P, Ruiz I, et al. (1981) A method for estimating the probability of adverse drug reactions. Clin Pharmacol Ther 30: 239-245.

5. Aster RH, Bougie DW (2007) Drug-induced immune thrombocytopenia. N Engl J Med 357: 580-587.

6. Cines DB, Bussel JB, Liebman HA, Luning Prak ET (2009) The ITP syndrome: pathogenic and clinical diversity. Blood 113: 6511-6521.

7. Vitale J, Carbone F (2011) Hemorrhagic herpes zoster. Lancet 378: 1324. 